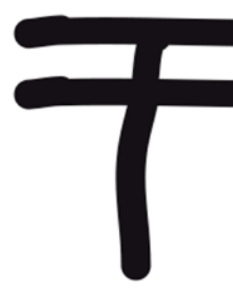

REVISTA DE ESTUDIOS E INVESTIGACIÓN

EN PSICOLOGÍA Y EDUCACIÓN

ISSN: 1138-1663; elSSN: 2386-7418

UDC / UMinho

2018, Vol. 5, No.1, 1-8.

DOI: https://doi.org/10.17979/reipe.2018.5.1.3095

\title{
Academic goals in blind and partially sighted students: a differential analysis and goal profiles
}

\author{
Metas académicas en el alumnado con deficiencia visual parcial y total: un análisis \\ diferencial y perfiles de metas
}

\author{
Irene Jover $(\mathbb{D} *$, Leandro Navas $(\mathbb{D} *$, Francisco Pablo Holgado-Tello $(\mathbb{D} * *$ \\ *Universidad de Alicante, **Universidad Nacional de Educación a Distancia
}

\begin{abstract}
The present work was based on goal orientation theory that represent the reasons to perform a task and the criteria to evaluate it. However, few studies have explored goal orientations in students with visual impairment. The objective of this study was to determine whether the goals pursued by blind students different from those of partially sighted students. Participants comprised 171 students, from different stages of the education system (from Primary Education to University Education) with ages between 8 and 27 years old, of which 109 were blind, and 62 partial visual impairment, which respond to an adaptation of the Achievement Goal Tendencies Questionnaire. The results indicate that students with total visual impairment have lower average scores on social reinforcement goals, not in contrast to learning goals, achievement goals and performance goals, where no significant differences were found. Three different goal orientation profiles were obtained. The first stands out for obtaining high scores in learning goals; the subjects of the second group are defined by obtaining high scores in learning goals, social reinforcement goals and performance goals; and the subjects of the third group are characterized by their low scores on learning goal, social reinforcement goals and achievement goals. The results of the discriminant analyses show that there are differences in these profiles depending on the degree of visual disability and that the achievement goals do not have discriminating power. These findings have educational implications as regards motivation.
\end{abstract}

Keywords: learning goals, social reinforcement goals, achievement goals, performance goals, goal orientation

Resumen

El presente trabajo se enmarca en la teoría de orientación a metas que representan las razones para realizar una tarea y los criterios para evaluarla. Sin embargo, las orientaciones de meta han sido poco estudiadas en alumnos con deficiencia visual. El objetivo de este estudio es averiguar si las metas que persigue el alumnado con deficiencia visual se diferencian según la deficiencia sea total o parcial. Participan 171 estudiantes de las diferentes etapas del sistema educativo (desde Primaria hasta Universidad) con edades entre 8 y 27 años, de los cuales 109 tenían discapacidad visual total y 62 parcial, que responden a una adaptación del Achievement Goal Tendencies Questionnaire. Los resultados indican que los estudiantes con deficiencia visual total presentan puntuaciones medias más bajas en las metas de refuerzo social, no en cambio en metas de aprendizaje, metas de logro y metas de rendimiento donde no hay diferencias significativas. Se obtienen tres perfiles de meta

Irene Jover (D000-0001-7475-863X y Leandro Navas (D000-0003-3005-9073, Departamento de Psicología Evolutiva y Didáctica. Universidad de Alicante. Carretera de San Vicente del Raspeig s/n, 03690 San Vicente del Raspeig, Alicante, España.

Francisco Pablo Holgado-Tello (D0000-0003-0769-5901, Departamento de Metodología de las Ciencias del Comportamiento. Universidad Nacional de Educación a Distancia (UNED), Calle Juan del Rosal, 10, 28040, Madrid. España.

Correspondencia relativa a este artículo: Francisco Pablo Holgado-Tello - pfholgado@psi.uned.es 
diferentes. El primero destaca por obtener puntuaciones altas en metas de aprendizaje; los sujetos del segundo grupo se definen por obtener puntuaciones altas en metas de aprendizaje, metas de refuerzo social y metas de rendimiento; y los sujetos del tercer grupo se caracterizan por sus bajas puntuaciones en metas de aprendizaje, en metas de rendimiento y metas de logro. Los resultados de los análisis discriminantes muestran que hay diferencias en esos perfiles en función del grado de discapacidad visual y que las metas de logro no tienen poder discriminante. Se derivan implicaciones educativas de tipo motivacional.

Palabras clave: learning goals, social reinforcement goals, achievement goals, performance goals, goal orientation

The concept of goal orientation in learning has acquired great importance in research on academic motivation (Brophy, 2004, 2005; Closas, Sanz de Acedo \& Ugarte, 2011; Dweck, 1986; González, Valle \& González-Pienda, 1996; Inglés, Martínez-Monteagudo, García-Fernández, Valle \& Castejón, 2015; Navas, Marco \& Holgado, 2012; Pintrich \& Schunk, 2002; Veas, Castejón, Gilar \& Miñano, 2015; Woolfolk, 2014). The theory has inspired a large number of studies, which have shown that academic goals determine student motivation and constitute the reasons for performing a task, the aims pursued in doing so, and the criteria for assessing its execution.

According to the two-dimensional model (Ames, 1992; Dweck, 1986), there are two types of goal: learning goals (focused on understanding and learning) and performance goals (focused on self and performance). Learning orientation has been considered more adaptive and has been associated with a series of positive mediators in learning; in contrast, performance orientation has been viewed as less effective and has been related to negative mediators.

In addition to the learning goals defined by Dweck (1986), the three-dimensional model (Hayamizu, Ito \& Yohiazaki, 1989; Hayamizu \& Weiner, 1991), on the other hand, proposes two sub-categories within performance goals: achievement goals (that imply obtaining the best performance and the best possible grades) and social reinforcement goals (who express reasons such as seeking approval and avoiding rejection from others). The emergence of three types of goals is justified by Hayamizu and Weiner (1991) because "Dweck emphasized avoiding challenges when measuring performance goals" (p. 233). The existence of these three types of goals has been confirmed in several studies (González, Navas \& Torregrosa, 2000; Núñez \& González-Pienda, 1994; Núñez, González-Pienda, García, González-Pumariega \& García, 1998; Valle et al., 2000).

Also, a four-dimensional model has been proposed that classifies goals into four categories: task goals, goals of self-assessment or self-orientation, goals of social assessment and reward goals (Núñez, González-Pienda, González-Pumariega, García \& Roces, 1997). Task goals lead students to learn and develop and improve their abilities. The goals of ego orientation lead the student to seek the satisfaction experience that follows success and avoid the negative feelings that accompany failure. The goals of social assessment make the student seek the assessment and approval of others. And reward goals lead the student to obtain awards or avoid losing situations or things that value. Several investigations have identified these four kinds of goals (Valle et al., 2003a, 2003b; Valle, Cabanach, Rodríguez, Núñez \& González-Pienda, 2006; Valle et al., 2008, 2009).

However, this conceptual and empirical approach is not uniform but rather has evolved from normative concepts towards other, multidimensional ones. From this perspective, the goals are defined as cognitive representations of what the students see them as trying to achieve. What is important is the content of the students' goals and how they strive to achieve academic and social outcomes (Wentzel. 1993). It is argued that motivation is related to multiple goals and that the same student can pursue different goals at the same time (Wentzel, 1999, 2000), and it has been established that these give rise to different motivational profiles (Alonso-Tapia, Huertas \& Ruiz, 2010; Barca-Lozano, Almeida, Porto-Rioboo, Peralbo-Uzquiano \& Brenlla-Blanco, 2012; Barca, Peralbo, Porto, Marcos \& Brenlla, 2011; Cecchini, González, Méndez-Giménez \& Fernández-Río, 2011; Navas \& Sampascual, 2008; Pekrun, Elliot \& Mayer, 2009; Phan, 2012). It appears that academic goals diversify with an increasing the level of education. Thus, for example, Navas, González and Torregrosa (2002) found the three classic goals (learning, social reinforcement and achievement) in primary education students, four types of goal in secondary education students, five in postcompulsory secondary education students and up to six different types of goal in university students.

Although goal orientations constitute an important motivational factor, they have not been studied in students with visual impairment, and this was the objective of the present study.

Students with visual impairment must use their other senses to comprehend their surroundings and act with minimal delay compared to sighted people (Herrera \& Ramírez, 1999; Rosa, Huertas \& Blanco, 1993). Visually impaired people need the help of others to apprehend the context, at least initially. Consequently, their satisfactory development depends on adults' attitudes towards them (Navas, Jover \& Castejón, 2017; Pelechano, De Miguel \& Ibáñez, 1995; Warren, 1984). Social interaction is thus 
extremely important for people with visual impairment, because they are more dependent and have reduced possibilities of movement and of understanding their physical and social environment (Bieber-Sucht, 1991; Rosa et al., 1986; Van Hasselt, 1983; Warren, 1984). Therefore, orientation, mobility and motivation are crucial capacities for these people.

The restrictions experienced by one student with visual impairment cannot be generalised to all other visually impaired students. The most influential factor is the level of visual loss (Núñez, 1999; Verdugo \& Caballo, 1995).

Students with visual impairment have unique educational needs. Imitation is limited or non-existent, and therefore learning requires greater effort and teaching activities that prioritise tactile, auditory and propioceptive perceptions (Navas et al., 2017; Núñez, 1999).

One might think that in order to prove their worth to others and to themselves, blind and partially sighted students would be more motivated to carry out their academic activities. Indeed, some studies (Holgado, Navas \& Jover, 2012; Jover, 2006, 2009; Jover, Navas \& Sampascual, 2008) have found that people with visual impairment have a different goal orientation structure to that obtained for sighted students.

This raises the question of whether the degree of visual impairment leads to differences in goal orientation. Consequently, the objective of the present study was to analyse whether the goals pursued by blind students differed from those of partially sighted students, and to determine motivational profiles as a function of degree of impairment.

\section{Method}

\section{Participants}

Participants comprised 171 students $(57.3 \%$ boys and $42.7 \%$ girls) with visual impairment, selected by means of non-probability convenience sampling among affiliates of the National Organisation of Spanish Blind People (Spanish acronym: ONCE). Of these, 36.3\% presented total visual impairment, with ages ranging from 9 to 26 years old $(M=15.81 \pm .56 ; D T=4.43)$ and $63.7 \%$ presented partial visual impairment, with ages ranging from 8 to 27 years old $(M=14.32 \pm .36 ; D T=3.80)$. All participants were students enrolled in different courses, according to the distribution of the Spanish educational system: $28.7 \%$ from Primary Education (from the fourth to the sixth course), $49.1 \%$ from Compulsory Secondary Education (from the first to the fourth course), $9 \%$ from Bachelor (first and second courses), $10.8 \%$ from University Education, and $2.4 \%$ from Vocational Training.

\section{Instruments}

We administered the Achievement Goal Tendencies Questionnaire developed by Hayamizu \& Weiner (1991), using the version created by González et al., (2000) which is tailored to students with visual impairment, either by using large print for partially sighted students or Braille for blind students. The questionnaire lists 20 reasons for studying, and subjects indicate the reasons why they study using a 5-point Likert type scale where 1 means "never" and 5 means "always or all the time". The questionnaire has obtained a reliability of between .89 and .71 . Given the characteristics of the participants, an exploratory factor analysis (EFA, principal factor with varimax rotation) was performed. The instrument consists of four factors (Holgado et al., 2012). Table 1 shows the factors, the items that compose them, the percentage of variance they explain, and their reliability (Conbrach alpha reliability coefficient).

Summary of the results of the Exploratory Factor Analysis

\begin{tabular}{lccc}
\hline Factor & Items & $\begin{array}{c}\text { Explained } \\
\text { variance (\%) }\end{array}$ & $\begin{array}{c}\text { Reliability } \\
\text { (alpha) }\end{array}$ \\
\hline Learning goals & 1 to 8 & 19.84 & .85 \\
Social reinforcement goals & 9 to 14 & 16.40 & .83 \\
Performance goals & 15 to 17 & 12.28 & .76 \\
Achievement goals & 18 to 20 & 9.66 & .69 \\
\hline
\end{tabular}

This factorial structure was validated by applying confirmatory factor analysis (Jover, 2009), yielding the following goodness of fit indices: $\chi^{2}(g l=161 ; p=.001)=$ 573.85; RMSEA $=.08 ;$ GFI $=.98 ;$ AGFI $=.97$. These results indicate that the four-dimensional model obtained in the EFA fits the data reasonably well.

\section{Procedure}

Students were selected through the directors of various Educational Resource Centres (ERC) affiliated to ONCE. The questionnaire was administered by peripatetic teachers and ERC coordinators. Teachers were instructed on how the questionnaire should be completed (anonymously, in a single session, in the students' usual classroom, and expressly indicating that the students' answers would not affect their marks and that therefore they should answer as honestly as possible). At the same time, students received an assurance that their anonymity and right to privacy would be maintained.

\section{Variables}

The variables considered were: a) academic goals (learning, social reinforcement, performance and achievement), and b) students' status (total or partial visual impairment).

\section{Design and data analysis}

A basic correlational design was employed, since there was no intentional manipulation of the variables and the subjects were selected using convenience sampling, participated on a voluntary basis and gave their verbal consent. Correlational, differential and discriminant analyses were performed on the data. 


\section{Results}

Using Pearson's $r$ correlation, the relations between all the variables were considerable. All the correlations, except one, were significant. They ranged from .20 (social reinforcement goals-learning goals) to .47 (performance goals-social reinforcement goals). It is notable that the degree of association between social and achievement goals was almost zero and statistically non-significant.

Table 2 presents the results obtained for the contrast of means for independent samples ( $t$-test) in which the grouping variable was the degree of visual impairment (total or partial) and the grouped variables were the goal orientations. For social goals, partially sighted students obtained a higher mean score than blind students.

Table 2

Group statistics based on visual impairment (total/partial)

\begin{tabular}{lcccccc}
\hline \multirow{2}{*}{ Goals } & $V I$ & $M$ & $D T$ & $\begin{array}{c}\text { Mean } \\
\text { difference }\end{array}$ & $t$ & $g l$ \\
\hline Learning & Total & 26.90 & 6.49 & -1.64 & -1.49 & 169 \\
Social & Partial & 28.54 & 7.13 & & & \\
reinforcement & Total & 13.14 & 6.53 & -2.52 & $-2.38^{*}$ & 169 \\
Partial & 15.67 & 6.75 & & & \\
Performance & Total & 19.77 & 4.42 & -1.07 & -1.55 & 169 \\
& Partial & 20.85 & 4.35 & & & \\
Achievement & Total & 12.56 & 2.90 & -0.23 & -0.53 & 169 \\
\hline
\end{tabular}

Note: $\mathrm{VI}=$ Visual impairment

$* p<.05$

A k-means cluster analysis was performed to establish students' profiles according to the scores they obtained for the goals. The method used was centroid linkage and the measure, Pearson's correlation, since the aim was to determine how subjects responded (Martínez-Arias, 1999). All the variables used in the clustering processes were relevant (Learning goals $F_{2 ; 168}=136.27 ; p<.001$; Social reinforcement goals $F_{2 ; 168}=163.30 ; p<.001 ;$ Performance goals $F_{2 ; 168}=29.72 ; p<.001$; and Achievement goals $F_{2}$; $168=5.23 ; p=.006$ ).

Table 3 shows the final cluster centroids for each variable. Students in the first cluster $(n=63)$ had high mastery goals, intermediate performance and achievement or reward goals and low social goals. Students in the second cluster $(n=52)$ presented high learning, social and performance goals and intermediate achievement goals. In the third cluster $(n=56)$, students' learning, social reinforcement, performance and achievement goals were below average. These three goal orientation profiles are depicted more clearly in Figure 1.

Table 3

The final cluster centroids

\begin{tabular}{lcccc}
\hline & Global & \multicolumn{3}{c}{ Clusters } \\
Goals & mean & 1 & 2 & 3 \\
\hline Learning & 27.95 & 32.21 & 31.15 & 20.18 \\
Social reinforcement & 14.75 & 10.70 & 23.02 & 11.64 \\
Performance & 20.46 & 20.68 & 23.25 & 17.63 \\
Achievement & 12.71 & 13.29 & 13.04 & 11.77 \\
\hline
\end{tabular}

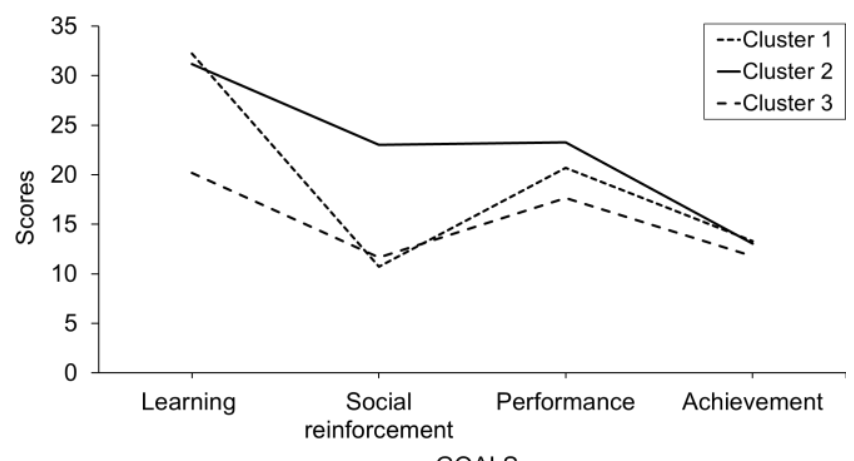

Figure 1. Goal profiles

GOALS

Table 4 gives the results of the contrast of functions (Wilks' Lambda test) in both groups and the eigenvalues obtained. The model was constructed in three steps using the first two canonical discriminant functions in the analysis. For blind students, the first discriminant function explained $83.4 \%$ of the variance and the canonical correlation was .82 , compared with $16.6 \%$ and .54 for the second function. In other words, the profiles differed more with respect to the first function. For partially sighted students, the first discriminant function explained $80.5 \%$ of the variance and the canonical correlation was .81, compared with $19.5 \%$ and .56 for the second function, indicating that the profiles differed more with respect to the first function.

Table 4

Tests of equality of means for the groups and eigenvalues obtained

\begin{tabular}{|c|c|c|c|c|c|c|c|c|}
\hline & \multicolumn{2}{|c|}{$\lambda$} & \multicolumn{2}{|c|}{$\chi^{2}$} & \multicolumn{2}{|l|}{$g l$} & & \\
\hline & Total & Partial & Total & Partial & & & & \\
\hline 1 to 2 & .23 & .23 & $84.12 *$ & $151.98 *$ & 6 & & & \\
\hline 2 & .71 & .68 & $19.72 *$ & $39.84 *$ & 2 & & & \\
\hline Function & & & $\%$ & ance & $\%$ & ated & Canon & relation \\
\hline & Total & Partial & Total & Partial & Total & Partial & Total & Partial \\
\hline 1 & 2.03 & 1.91 & 83.4 & 80.5 & 83.4 & 80.5 & .82 & .81 \\
\hline 2 & 0.40 & 0.46 & 16.6 & 19.5 & 100 & 100 & .54 & .56 \\
\hline
\end{tabular}


Finally, a Discriminant Analysis was conducted using the goals as predictors and the cluster as predicted variables. This was done to depict the capacity of each of the goals to explain the variability due to differences between the three student profiles. The achievement goal was not used in the analysis. Table 5 shows the structure matrix of the Discriminant Analysis. The discriminant functions correctly classified $88.7 \%$ of blind students and $93.6 \%$ of partially sighted students.

Table 5

Structure matrix

\begin{tabular}{lcccc}
\hline & \multicolumn{4}{c}{ Function } \\
& \multicolumn{3}{c}{1} & \multicolumn{2}{c}{2} \\
\cline { 2 - 5 } & Total & Partial & Total & Partial \\
\hline Learning goals & .52 & $.90+$ & $.85+$ & -.44 \\
Social reinforcement & .59 & .37 & $-.70+$ & $.76+$ \\
goals & & & & \\
Performance goals & $.50+$ & $.55+$ & -.25 & .47 \\
\hline
\end{tabular}

Note: + Greater absolute correlation between each variable and any discriminant function.

\section{Discussion}

This study had two objectives. The first was to determine whether goal orientations differed according to degree of visual impairment (total and partial).

Contrary to what is established in two-dimensional (Ames, 1992; Dweck, 1986) and three-dimensional models (González et al., 2000; Hayamizu et al, 1989; Hayamizu \& Weiner, 1991; Núñez \& González-Pienda, 1994; Núñez et al., 1998; Valle et al., 2000), in line with the results obtained in other research with students without visual disability (Núñez et al., 1998; Valle et al., 2003a, 2003b; Valle et al., 2006; Valle et al., 2008, 2009) four types of goals emerge: learning goals, social reinforcement goals, performance goals and achievement goals.

The results obtained show a statistically significant inter-relationship between the four goal orientations, with the exception of social and achievement goals. These findings indicate that the goals were not orthogonal and that the same subject could pursue different goals at the same time, in line with the idea of multiple goals described by Wentzel (1993, 1999, 2000). In addition, the social goals presented statistically significant differences, whereby partially sighted students obtained higher mean scores. It may be that their residual vision allows them to perceive the social and emotional reactions of others better, and they are therefore more motivated to obtain social approval. This is further supported by studies showing that people with total visual impairment present poor social functioning (Bieber-Sucht, 1991; Navas et al., 2017; Van Hasselt, 1983; Verdugo \& Caballo, 1995; Warren, 1984), manifested in a chronological delay in the development of social skills, less social contact, the existence of problems regarding social adaptation and isolation, a lack of assertiveness and poorer interpersonal social skills.

The second objective was to establish motivational profiles as a function of goal orientations, as it has been obtained in other studies (Alonso-Tapia et al., 2010; BarcaLozano et al., 2012; Barca et al., 2011; Cecchini et al, 2011; Pekrum et al., 2009). Three profiles were obtained consistent with those reported in other studies of students with visual impairment (Holgado et al., 2012; Jover, 2009). The first stands out for obtaining high scores in learning goals; the subjects of the second group are defined by obtaining high scores in learning goals, social reinforcement goals and performance goals; and the subjects of the third group are characterized by their low scores on learning goal, social reinforcement goals and achievement goals.

The discriminant analysis results indicate that for blind students, learning and social reinforcement goals were the most important variables in the second discriminant function, whereas academic performance goals were more important in the first function. However, for partially sighted students, learning and academic performance goals were the most important variables in the first discriminant function, while social goals were more important in the second function. In addition, the achievement or reward goals presented no discriminant power.

Taken together, this indicates that students were classified into one of the three profiles obtained as a function of different goals depending on their status (blind or partially sighted).

Exercising self-criticism, one of the main potential limitations of this study was that in reference to visual impairment (total or partial), no account was taken of when the impairment was acquired nor of its aetiology. It should be borne in mind that in terms of cognitive and social development, it is not the same to become blind after an accident as it is to be born blind; neither is the degree of acuity and visual field the same for all partially sighted people, since there is a vast difference between barely requiring any instrument to read and depending on assistive technology, as do some partially sighted people who are almost totally blind (Herrera \& Ramírez, 1999; Navas et al., 2017; Rosa et al., 1993; Rosa et al, 1986; Van Hasselt, 1983; Verdugo \& Caballo, 1995; Warren, 1984).

Nor did we consider students' sociocultural level, the quality of their affective relations at home, or their families' attitudes, which exert such a strong influence on students' perception of education. As Núñez (1999) and Pelechano et al. (1995) have noted, there is a close relationship between parents' attitudes and the levels of development attained by children with visual impairment but without other associated disorders.

Another important variable that was not considered was the age range of participants, from 8 to 27 years old. It appears that academic goals diversify with an increasing the level of education (Navas et al., 2002). Because we did not control for age or educational stage, it remains unclear 
in the present study whether the goal orientations studied were the result of visual impairment or, conversely, were determined by the different ages and educational stage of the participants.

Another critical issue is the use of a questionnaire of goals with a Likert scale, but "what do students say when asked to describe their goals in their own words? Remarkably, very few investigators have addressed this question" (Brophy, 2005, p. 170). It has been suggested that students rarely generate performance goals spontaneously and this is revealed when they are asked to describe their goals in their own words (Brophy, 2004; Navas et al., 2012).

In future research on the academic goals of people with visual impairment, these variables should be considered together with others such as learning contexts, attributions and self-concept.

In conclusion, the following findings should be highlighted: a) The only statistically significant differences obtained between blind and partially sighted students were for social reinforcement goals, with the latter group obtaining a higher mean score than the former. b) Three clusters or profiles were identified, which were used to classify the students according to the scores they obtained for the different goals. Of these, the ones that demonstrated the greatest discriminant power were learning goals, academic performance goals, and social reinforcement goals, although their discriminant capacity varied according to student status (blind or partially sighted).

\section{References}

Alonso-Tapia, J., Huertas, J. A., \& Ruiz, M. A. (2010). On the nature of motivational orientations. Implications of assessed goals and gender differences for motivational goal theory. The Spanish Journal of Psychology, 13, 232-243. https://doi.org/10.1017/s1138741600003814

Ames, C. (1992). Achievement goals and the classroom motivational climate. In D. H. Schunk \& J. Meece (Eds.), Student percepctions in the classroom (pp. 327348). Hillsdale, NJ: Erlbaum.

Barca-Lozano, A., Almeida, L., Porto-Rioboo, A. M., Peralbo-Uzquiano, M., \& Brenlla-Blanco, J. C. (2012). School motivation and achievement: the impact of academic goals, learning strategies and self-efficiency. Anales de Psicología, 28(3), 848-859. https://doi.org/ 10.6018/analesps.28.3.156101

Barca, A., Peralbo, M., Porto, A. M., Marcos, J. L., \& Brenlla, J. C. (2011). Metas académicas del alumnado de Educación Secundaria Obligatoria (ESO) y Bachillerato con alto y bajo rendimiento escolar [Academic goals of high and low academic achievers in mandatory secondary education and optional advanced Secondary Education]. Revista de Educación, 354, 297299. https://doi.org/10.4438/1988-592X-RE-2011-354003
Bieber-Sucht, R. (1991). The use of drama to help visually impareid adolescents acquire social skills. Journal of Visaul Impairment and Blindness, 85(8), 340-341.

Brophy, J. (2005). Goal theorists should move on from performance goals. Educational Psychologist, 40(3), 167-176. https://doi.org/10.1207/s15326985ep4003_3

Brophy, J. (2004). Motivation student to learn (2 $2^{\text {nd }}$ ed.). Mahwah, NJ: Lawrence Erlbaum Associates.

Cecchini, J. A., González, C., Méndez-Giménez, A., \& Fernández-Río, J. (2011). Achievement goals, social goals, and motivational regulations in physical education settings. Psicothema, 23(1), 51-57. http:// www.psicothema.com/english/psicothema.asp?id=3849

Closas, A. H., Sanz de Acedo, M. L., \& Ugarte, M. D. (2011). An explanatory model of the relations between cognitive and motivational variables and academic goals. Revista de Psicodidáctica, 16(1), 19-38. http:// www.ehu.eus/ojs/index.php/psicodidactica/article/view $/ 1142$

Dweck, C.S. (1986). Motivational processes affecting learning. American Psychologist, 41, 1040-1048. https://doi.org/10.1037//0003-066x.41.10.1040

González, C., Navas, L., \& Torregrosa, G. (2000). Las metas en situación de aprendizaje: Un análisis en Primaria y Secundaria Obligatoria. In E. Marchena \& C. Alcalde (Coord.), La perspectiva de la educación en el siglo que empieza [The prospect of education in the new century begins] (pp. 744-748). Cádiz: Servicio de Publicaciones de la Universidad de Cádiz.

González, R., Valle, A., \& González-Pienda, J.A. (1996). Una aproximación teórica al concepto de metas académicas y su relación con la motivación escolar [A theoretical approach to concept of academic goals and their relationship with school motivation]. Psicothema, 8, 45-61. http://www.psicothema.com/pdf/4.pdf

Hayamizu, T., Ito, A., \& Yohiazaki, K. (1989). Cognitive motivational process mediated by achievement goal tendencies. Japonese Research, 31, 179-189. https:// doi.org/10.4992/psycholres1954.31.179

Hayamizu, T., \& Weiner, B. (1991). A test of Dwech's model of achievement goals are related to perceptions of ability. Journal of Experimental Education, 59, 226234. https://doi.org/10.1080/00220973.1991.10806562

Herrera, F., \& Ramírez, I. (1999). La deficiencia visual: Intervención psicopedagógica. In M. A. Lou \& N. López (Coords.), Bases psicopedagógicas de la Educación Especial [Psycho-pedagogical Bases of Special Education] (pp. 137-160). Madrid: Pirámide.

Holgado, F. P., Navas, L., \& Jover, I. (2012). Academic Goal Profiles: A Comparison of Blind and Sighted Students. The Spanish Journal of Psychology, 15(3). https://doi.org/10.5209/rev_SJOP.2012.v15.n3.39395

Inglés, C. J., Martínez-Monteagudo, M. C., GarcíaFernández, J. M., Valle, A., \& Castejón, J. L. (2015). Goal Orientation Profiles and Self-Concept of Secondary School Students. Revista de Psicodidáctica, 20, 
99-116. https://doi.org/10.1387/RevPsicodidact.1023

Jover, I. (2009). Las metas académicas: análisis comparativo entre estudiantes videntes y estudiantes con deficiencia visual (Tesis doctoral ). Universidad de Alicante, Alicante, España.

Jover, I. (2006). Memoria para la obtención de la suficiencia investigadora (DEA). Universidad de Alicante, Alicante, España.

Jover, I., Navas, L., \& Sampascual, G. (2008). Metas académicas en alumnos con ceguera y deficiencia visual [Academic goals of blindo r visually impaired students]. Revista Española de Pedagogía, 239, 49-63. https:// revistadepedagogia.org/wp-content/uploads/2008/06/2 39-03.pdf

Martínez- Arias, R. (1999). El análisis multivariante en la investigación científica [Multivariate analysis in scientific research]. Madrid: La Muralla.

Navas, L. González, C., \& Torregrosa, G. (2002). Metas de aprendizaje: Un análisis transversal de las estructuras factoriales que presentan [Learning goals : A crosssectional analysis of factorial structures present]. Revista Psicología General y Aplicada, 55(4), 553-564. https://dialnet.unirioja.es/servlet/articulo?codigo=294343

Navas, L., Jover, I., \& Castejón, J. L. (2017). Dificultades de desarrollo y aprendizaje asociadas a la discapacidad visual. In J. L. Castejón \& L. Navas (Eds.), Dificultades y trastornos del aprendizaje y del desarrollo en infantil y primaria [Difficulties and learning disabilities and developmental kindergarten and primary] (pp. 269309). Alicante, Spain: ECU.

Navas, L., Marco, V., \& Holgado, F. P. (2012). Las metas de ejecución: su inexistencia en los estudiantes de conservatorio [Performance goals: your non students in Conservatory]. Revista de Investigación en Educación, 10(1), 172-179. http://reined.webs.uvigo.es/ojs/index. php/reined/article/viewFile/395/219

Navas, L., \& Sampascual, G. (2008). Un análisis exploratorio y predictivo sobre las orientaciones de meta y sobre el contenido de las metas de los estudiantes [An exploratory and predictive analysis on goal orientations and the content of student goals]. Horizontes Educacionales, 13(1), 23-33. http://eq38.fdo-may.ubiobio.cl/horizontes/Revista/files /revistas/2008/13_1/2\%20analisis\%20exploratorio $\% 20$ y\%20predictivo $\% 20$ sobre $\% 201$ as $\% 20$ orientaciones $\% 2$ 0de $\% 20$ meta $\% 20 y \% 20$ sobre $\% 20$ el $\% 20$ contenido $\% 20$ d e\%20las\%20metas\%20de\%201os\%20estudiantes.pdf

Núñez, J. C., \& González-Pienda, J. A. (1994). Determinantes del rendimiento académico [Determinants of academic performance]. Oviedo, Spain: Servicio de Publicaciones de la Universidad de Oviedo.

Núñez, J. C., González-Pienda, J. A., García, M. S., González-Pumariega, S., \& García, S. I. (1998). Estrategias de aprendizaje en estudiantes de 10 a 14 años y su relación con los procesos de atribución causal, el autoconcepto y las metas de estudio. Estudios de Psicología, 59, 65-85. https://doi.org/10.1174/0210939 9860400739

Núñez, J. C., González-Pienda, J. A., González-Pumariega, S., García, M., \& Roces, C. (1997). Cuestionario para la evaluación de metas académicas en secundaria (CEMA-II) [Questionnaire for the evaluation of academic goals in secondary school (CEMA-II)]. Oviedo, Spain: Departamento de Psicología. Universidad de Oviedo.

Núñez, M. A. (2000). El desarrollo psicológico del niño ciego. Aspectos generales. In M. R. Villalba (Dir.), Aspectos evolutivos y educativos de la deficiencia visual [Evolutionary and educational aspects of visual impairment] (pp. 63-130). Madrid, Spain: ONCE.

Pekrum, R., Elliot, A. J., \& Maier, M. A. (2009). Achievement goals and achievement emotions: Testing a model of their joint relations with academic performance. Journal of educational Psychology, 101(1), 115-135. https://doi.org/10.1037/a0013383

Pelechano, V., De Miguel, A., \& Ibáñez, I. (1995). Las personas con deficiencias visuales. In M. A. Verdugo (Dir.), Personas con discapacidad. Perspectivas psicopedagógicas y rehabilitadoras [People with disabilities. Psychopedagogical and rehabilitative perspectives] (pp. 325-392). Madrid, Spain: Siglo XXI.

Phan, H. P. (2012). An examination of achievement goals in learning: A quasi -quantitative approach. Electronic Journal of Research in Educational Psychology, 10(2), 505-544. http://www.investigacionpsicopedagogica.org /revista/new/english/ContadorArticulo.php?724

Pintrich, P. R., \& Schunk, D. H. (2002). Motivation in education: Research and applications (2a ed.). Boston, MA: Allyn \& Bacon.

Rosa, A., Huertas, J. A., \& Blanco, F. (1993). Psicología de la ceguera y psicología general. In A. Rosa \& E. Ochaita (Eds.), Psicología de la ceguera [Psychology of blindness] (pp. 319-361). Madrid: Alianza.

Rosa, A., Ochaita, E., Moreno, E., Fernández, E., Carretero, M., \& Pozo, J. I. (1986). Aspectos cognitivos del desarrollo psicológico de los ciegos [Cognitive aspects of psychological development of the blind]. Madrid: MEC.

Valle, A., Cabanach, R., Núñez, J. C., González-Pienda, J. A., Rodríguez, S., \& Piñeiro, I. (2003a). Multiple goals, motivation and academic learning. British Journal of Educational Psychology, 73, 71-87. https://doi.org/10. 1348/000709903762869923

Valle, A., Cabanach, R., Núñez, J. C., González-Pienda, J. A., Rodríguez, S., \& Piñeiro, I. (2003b). Cognitive, motivational and volitional dimensions of learning: An empirical test of a hypothetical model. Research in Higher Education, 44, 557-580. https://doi.org/10.1023/ a:1025443325499

Valle, A., Cabanach, R., Rodríguez, S., Núñez, J. C., \& González-Pienda, J. A., (2006). Metas académicas, 
estrategias cognitivas y estrategias de autorregulación del estudio [Academic goals, cognitive and selfregulatory strategies]. Psicothema, 18(2), 165-170. http://www.psicothema.com/english/psicothema.asp?id $=3193$

Valle, A., González-Cabanach, R., Núñez, J. C., Suárez, J. M., Piñeiro, I., \& Rodríguez, S. (2000). Enfoques de aprendizaje en estudiantes universitarios [Approaches to learning in university students]. Psicothema, 12(3), 368-375. http://www.psicothema.com/english/psicothe ma.asp? $\mathrm{id}=344$

Valle, A., Núñez, J. C., González-Cabanach, R., Rodríguez, S., González-Pienda, J. A., \& Rosário, P. (2009). Perfiles motivacionales en estudiantes de secundaria: análisis diferencial en estrategias cognitivas, estrategias de autorregulación y rendimiento académico [Middle school students, motivational profiles: Analyzing the differences in cognitive strategies, self-regulated strategies and academic achievement]. Revista Mexicana de Psicología, 26(1), 113-124. http://www. redalyc.org/html/2430/243016317011/

Valle, A., Núñez, J. C., González-Cabanach, R., Rodríguez, S., González-Pienda, J. A., \& Rosário, P. (2008). Capacidad predictiva de las metas académicas sobre el rendimiento en diferentes áreas curriculares [Predictive capacity of academic goals on performance in different curricular áreas]. Revista Latinoamericana de Psicología, 40(1), 111-122. http://www.redalyc.org/pdf 1805/80500109.pdf

Van Hasselt, V. B. (1983). Social Adaptation in the Blind. Clinical Psychology Review, 31(1), 87-102. https://doi. org/10.1016/0272-7358(83)90007-7

Veas, A., Castejón, J. L., Gilar, R., \& Miñano, P. (2015). Academic Achievement in Early Adolescence: The Influence of Cognitive and Non-Cognitive Variables. The Journal of General Psychology, 142(4), 273-294. https://doi.org/10.1080/00221309.2015.1092940

Verdugo, M. A., \& Caballo, C. (1995). Habilidades sociales en personas con déficit visual. En M. A. Verdugo (Dir.) Personas con discapacidad. Perspectivas psicopedagógicas y rehabilitadoras [People with disabilities. educational psychology and rehabilitative prospects] (pp. 457-505). Madrid: Siglo XXI.

Warren, D.H. (1984). Blindness and early childhood development. Nueva York: American Foundation for the Blind.

Wentzel, K. R. (2000). What is it that I'm trying to achieve? Classroom goals from a content perspective. Contemporary Educational Psychology, 25, 105-115. https://doi.org/10.1006/ceps.1999.1021

Wentzel, K. R. (1999). Social-motivational processes and interpersonal relationships: implications for understanding motivation at school. Journal of Educational Psychology, 91(1), 76-97. https://doi.org/ 10.1037/0022-0663.91.1.76

Wentzel, K. R. (1993). Motivation and achievement in early adolescence: The role of multiple classroom goals. Journal of Early Adolescence, 13(1), 4-20. https://doi. org/10.1177/0272431693013001001

Woolfolk, A. (2014). Psicología Educativa [Educational Psychology] (12 ${ }^{\text {th }}$ ed.). México: Pearson.

Fecha de recepción: 11 de octubre de 2017. Fecha de revisión: 7 de febrero de 2018. Fecha de aceptación: 1 de marzo de 2018. Fecha de publicación: 1 de julio de 2018. 